\title{
DUAL-PROCESSING AND THE REPRESENTATIONAL HYPOTHESIS: ACCOUNTING FOR THE EMERGENCE OF LANGUAGE
}

\author{
ANDREW FEENEY \\ andrew.feeney@northumbria.ac.uk \\ Department of Humanities, Northumbria University, Newcastle upon Tyne, United \\ Kingdom
}

There are well-rehearsed arguments, including those that appeal to aspects of psycholinguistic processing and language acquisition, that suggest that language has certain properties that distinguish it from domain general capacities. However, I argue that this position is based on a misreading of the properties, and relationship, of language and thought.

In the first instance there is a fundamental dichotomy: either humans think in the languages they speak, or in another, unarticulated system. I agree with Penn et al. that 'the adaptive advantages of being able to reason in a relational fashion have a certain primacy over the communicative function of language' (2008: 123). Language as a system of symbolic representation could not have evolved if conceptual categories did not already exist. The nature of such cognition is central to Dual-Processing Theory which is founded on a substantial body of evidence that suggests that modern humans are characterized by two fundamentally distinctive modes of reasoning (Eagleman, 2011; Evans, 2010). For while we share with nonhuman animals a similar system of fast, intuitive cognitive processing based on evolutionarily older brain systems - System 1 (Frankish, 2009) - we have also, at some point in the last 7.5 million years or more, evolved a capacity for systematic, computational thought that enables us to be logical and reflective and on occasions to override instinctive, associative reactions (System 2). The questions in relation to language evolution are: when did these developments occur and what is the relation to language? 
Drawing on recent findings from ethology, evolutionary biology and paleontology it becomes clear that there were two significant periods in the evolution of human cognition corresponding to stages of punctuated equilibrium (Gould and Eldredge, 1993). The first of these followed a period, approximately two million years ago, in which there were a comparatively large number of changes to genes and genomic regions (especially in the Human Accelerated Region 1) with consequences for brain lateralization, connectivity and overall brain size (Kamm et al., 2013). This was associated with the first irrefutable evidence of changes to cognitive behavior resulting in sophisticated (mode 2) tool use, migration out of Africa and probable use of fire (Beyene et al, 2012; Wynn, 2012; Lynch and Granger, 2008). Such accomplishments are indicative of cooperation beyond that exhibited by any preceding hominins, and I agree with Levinson and Evans that 'there can be no doubt that premodern humans were talking' (2010: 2742). I suggest that the first of these linguistic hominins belonged to a species such as Homo erectus and were endowed with a protolanguage involving the simple concatenation of symbols, lacking the structural complexity that characterizes modern human language (Jackendoff, 2002; Tallerman, 2012).

The following period of a million years or so, although witness to some physical adaptations that benefited vocalization, was characterized by almost complete cultural stasis indicative of species with a cognitive capacity that lacked substantial creativity and was essentially still of type System 1. Until, around 500 thousand years ago, there was a second intense episode of evolutionary activity involving further growth and reorganization of the brain which resulted in an advanced theory of mind and a creative, recursive System 2 type cognitive processing and the emergence of Homo sapiens.

Modern, complex language emerged from the precursor protolanguage to be utilized to represent externally this mind internal universal cognition. This is the conception of language in the Representational Hypothesis (e.g. Burton-Roberts, 2011) in which there is a clear distinction between a mind internal structured cognition - the sole locus of semantics and syntax (Carey, 2011; Fodor, 1975, 2008; Harnard, 2010; Wynn et al., 2009) - and a phonological system for its semiotic representation. Despite appearances to the contrary, language is not, I claim, special in the sense of being a hardwired module of the mind. Indeed, the posited evolution of such a module presents severe strains on plausibility as evidenced in the weaknesses which Fitch, Hauser and Chomsky (2005) and Pinker and Jackendoff (2005) detect in each other's hypotheses. What is special, and what evolved in our species as the human faculty for language, is the 
capacity for representing thoughts within the constraints of symbolic systems. Languages have the appearance of hierarchy and recursion by virtue of representing a system, of conceptual structure, that is truly hierarchical and recursive.

\section{References:}

Beyene, Y., Katoh, S., Woldegabriel, G., Hart, W. K., Uto, K., sudo, M., Kondo, M., Hyodo, M., Renne, P. R., suwa, G., \& Asfaw, B. (2012). The characteristics and chronology of the earliest Acheulean at Konso, Ethiopia. Proceedings of the National Academy of Science 110, 5, 1584-1591.

Burton-Roberts, N. (2011). On the grounding of syntax and the role of phonology in human cognition. Lingua, 121, 2089-2102.

Carey, S. (2011). Precis of The Origin of Concepts. Behavioral and Brain Sciences. 34, 113-U117

Eagleman, D.(2011). Incognito : the secret lives of the brain. Edinburgh: Canongate.

Evans, J. S. B. T. (2010). Thinking twice: two minds in one brain. Oxford: Oxford University Press.

Fitch, W. T., Hauser, M. D. and Chomsky, N. (2005). The evolution of the language faculty: Clarifications and implications. Cognition. 97, 179-210.

Fodor, J. A. (1975). The language of thought. New York: Crowell

Fodor, J A. (2008). LOT 2 : The language of thought revisited. Oxford: Oxford University Press

Frankish, K. (2009). Systems and levels: Dual-system theories and the personalsubpersonal distinction. In J. S. B. T. Evans \& K. Frankish. (Eds.) In two minds: dual processes and beyond. Oxford: Oxford University Press.

Gould, S. J. \& Eldredge, N. (1993). Punctuated equilibrium comes of age. Nature, 366, 223-227.

Harnad, S..(2010). Eliminating the "concept" concept. Behavioral and Brain Sciences. 33, 213-+

Jackendoff, R.( 2002). Foundations of language : brain, meaning, grammar, evolution. Oxford: Oxford University Press.

Kamm, G. B., Pisciottano, F. Kliger, R. \& Franchini, L. F. (2013). The Developmental Brain Gene NPAS3 Contains the Largest Number of Accelerated Regulatory Sequences in the Human Genome. Molecular Biology and Evolution. 30, 1088-1102

Levinson, S. C. \& Evans, N. (2010). Time for a sea-change in linguistics: Response to comments on 'The Myth of Language Universals'. Lingua, 120, 2733-2758.

Lynch, G. \& Granger, R. (2008). Big brain: the origins and future of human intelligence. Basingstoke: Palgrave Macmillan.

Penn, D. C., Holyoak, K. J. \& Povinelli, D. J. (2008). Darwin's mistake: Explaining the discontinuity between human and nonhuman minds. Behavioral and Brain Sciences, 31, 109-+.

Pinker, S. and Jackendoff, R. (2005). The faculty of language: what's special about it? Cognition, 95 (2), 201-236.

Tallerman, M. (2012). Protolanguage. In: M. Tallerman, M. \& K. R. Gibson, (Eds.) The Oxford Handbook of Language Evolution. Oxford: Oxford University Press. 
Wynn, T. (2012). The Palaeolithic Record. In: M. Tallerman, M. \& K. R. Gibson (Eds.) The Oxford Handbook of Language Evolution. Oxford: Oxford University Press.

Wynn, T., Coolidge, F. L. \& Bright, M. (2009). Hohlenstein-Stadel and the Evolution of Human Conceptual Thought. Cambridge Archaeological Journal. 19, 73-83 